\title{
Development of home textiles inspired from mosaic tile motifs
}

\section{Jaskiran Kaur and Vandana Gandotra}

Received: 17.08.2020; Revised: 01.11.2020; Accepted: 21.11.2020

See end of the paper for authors' affiliations

\section{Jaskiran Kaur}

Department of Apparel and

Textile Science, College of

Home Science, Punjab

Agricultural University,

Ludhiana (Punjab) India

Email : jaskirank4@gmail.com
ABSTRACT : The study will help the designers in designing of various other products inspired from mosaic tiles motifs using screen printing. The present study would inspire the designers to create innovate designs to add more variety in the market. The study will help the designers in designs various products inspired from other tile motifs. A similar study on designing of other garments as well as accessories can be conducted. A similar study on product development through screen printing using other motifs can be conducted.

KEY WORDS: Home textiles, Mosaic tile motifs

- HOW TO CITE THIS PAPER : Kaur, Jaskiran and Gandotra, Vandana (2020). Development of home textiles inspired from mosaic tile motifs. Asian J. Home Sci., 15 (2) : 314-317, DOI: 10.15740/HAS/AJHS/ 15.2/314-317. Copyright@ 2020: Hind Agri-Horticultural Society. 